\title{
A TECHNIQUE FOR PERFUSION OF RAT TESTES IN SITU THROUGH THE INTERNAL SPERMATIC ARTERIES
}

\author{
P. M. FREDERIK AND L. G. VAN DOORN \\ Department of Biochemistry, Division of Chemical Endocrinology, and \\ Department of Cell Biology and Genetics, Medical Faculty, Erasmus University, \\ Rotterdam, The Netherlands
}

(Received 11th September 1972)

For studying the action of hormones on the testis, perfusion techniques have certain advantages (Eik-Nes \& Hall, 1965), such as minimal peripheral conversion or dilution of a labelled compound before it reaches the testes. Techniques for the perfusion of rabbit testes (VanDemark \& Ewing, 1963) and the testes of sheep and goats have been described. Unlike the rat testis (see Christensen \& Mason, 1965; Cooke, de Jong, van der Molen \& Rommerts, 1972; Rommerts, van Doorn, Galjaard, Cooke \& van der Molen, 1973), however, the rabbit, sheep and goat testes have the disadvantage that after the perfusion, they cannot be dissected into seminiferous tubules and interstitial tissue. This paper describes a technique for the perfusion of rat testes in situ and the evidence derived by this procedure for an oestradiol-17 $\beta$-binding macromolecule in isolated interstitial tissue.

A schematic outline of the perfusion apparatus is shown in Text-fig. 1 . Providing a normal flow of 1.5 to $3 \mathrm{ml} / \mathrm{min}$ was maintained, the temperature of the testis tissue measured with an NTC thermistor probe was $31^{\circ} \mathrm{C}$.

The perfusion medium used was a Krebs-Ringer bicarbonate buffer, $\mathrm{pH}$ $7 \cdot 4$, containing $1 \mathrm{mmol}$ glucose and 10 i.u. heparin $/ \mathrm{ml}$. Labelled oestradiol $\left(\left[2,4,6,7-{ }^{3} \mathrm{H}_{4}\right]\right.$ oestradiol- $17 \beta$, specific activity $100 \mathrm{Ci} / \mathrm{mmol}$; Radiochemical Centre, Amersham, England) was checked for radiochemical purity by paper and thin-layer chromatography. Oestradiol-17 $\beta(10 \mu \mathrm{Ci})$ was dissolved in 0.5 $\mathrm{ml}$ Krebs-Ringer bicarbonate buffer and perfused into the testes as described below.

The mature Wistar rats used were allowed free access to food and water up to the moment of ether anaesthesia. The abdomen was opened by a mid-line incision and the intestines were displaced to the right. The peritoneum was stripped from the aorta between the level of the left renal vein and the common iliac arteries (see Text-fig. 2), and 200 i.u. heparin were injected into the liver. The retrograde cannula (a hypodermic needle $40 \mathrm{~mm}$ long $\times 1.2 \mathrm{~mm}$ o.d., with a slightly blunted tip) was inserted at the bifurcation of the aorta. The tip of the cannula was moved cranially close to the origin of the left internal spermatic artery and then fixed with a ligature placed cranial to the origin of the ileolumbar arteries. By means of the roller pump, the pressure in the perfusion 
system was kept at the level of the blood pressure in the aorta (about $80 \mathrm{~mm} \mathrm{Hg}$ ). The jaws of an arterial clamp were modified (Text-fig. 2) to allow clamping of the aorta in the small region between the branching of the left renal artery and the aortic crossing of the left renal vein. After clamping the aorta, the internal spermatic arteries were perfused with medium. When the testes were brought into the peritoneal cavity through the inguinal canals, they appeared pale, indicating the replacement of blood by buffer in the testis circulation.

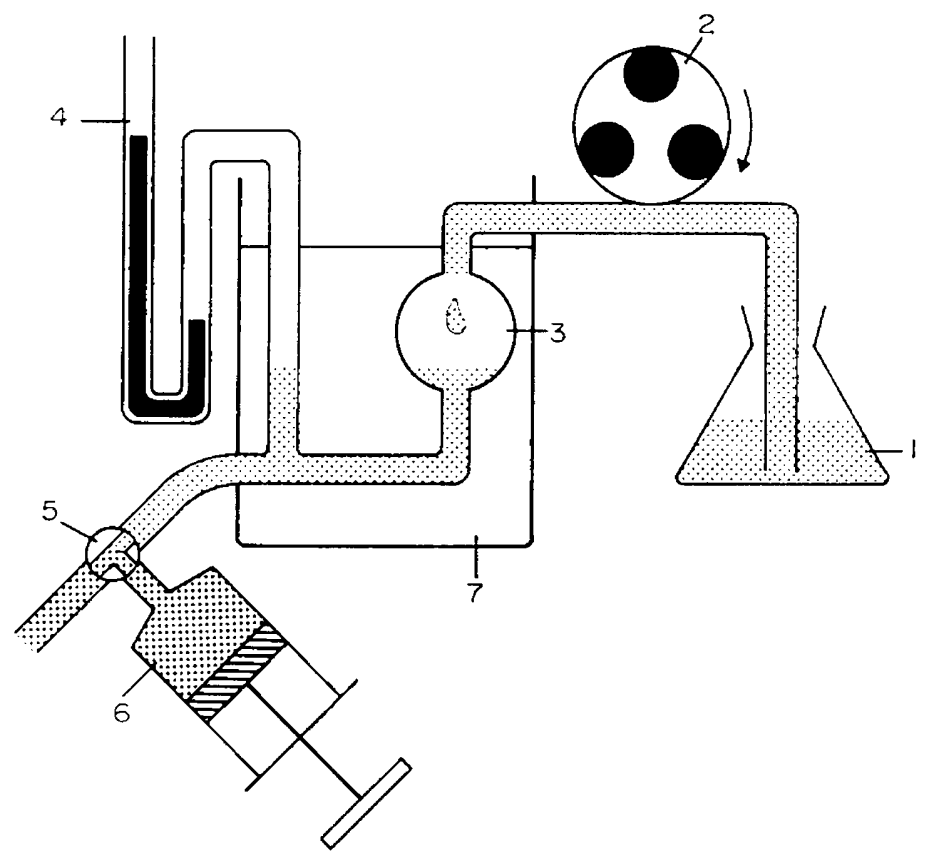

Text-Fig. 1. Perfusion apparatus. The perfusion medium was pumped from the storage flask (1) by a roller pump (2) to the bubble trap (3). The flow rate in the perfusion system was determined by counting the droplets falling into the bubble trap. The perfusion pressure was measured by a mercury-filled U-tube (4) connected to the infusion line coming from the bubble trap. A three-way stopcock (5) was interposed at a short distance from the end of the infusion line. Through this stopcock, the contents of a syringe (6)could be added to the perfusion medium under a controlled pressure. As many parts as possible of the perfusion apparatus were placed in a temperature-controlled water bath (7) kept at $40^{\circ} \mathrm{C}$.

After perfusion of buffer for $5 \mathrm{~min}$, the roller pump was stopped and ${ }^{3} \mathrm{H}$ Iabelled oestradiol-17 $\beta$ was injected into the perfusion system by means of a syringe (6, Text-fig. 1) under controlled pressure. Perfusion by means of the roller pump was restored and continued for $1 \mathrm{~min}$. The clamp on the aorta was then released and the testes were flushed with blood for less than 1 min, after which they were removed from the animal and kept at 0 to $4^{\circ} \mathrm{C}$ during the isolation of the oestradiol-17 $\beta$ receptor.

To prevent direct transfer of the infused compounds to the general circulation, perfusion has to take place only through the internal spermatic arteries. The outlet of the cannula was moved up the aorta close to the origin of the left internal spermatic artery (Text-fig. 2), thus excluding the lumbar arteries from 
supply of blood or perfusion medium. The origin of the left ileo-lumbar artery is variable (Greene, 1963). The artery was excluded from the perfusion by fixing the cannula with a ligature cranial to its origin. With some animals, it was only possible to clamp the aorta cranial to the origin of the left renal artery. The left renal artery and vein were then also clamped near the hilus. With these precautions, perfusion will take place almost exclusively through the internal spermatic arteries. Before entering the general circulation, a small amount of the medium enters organs other than the testes through tiny branches of the

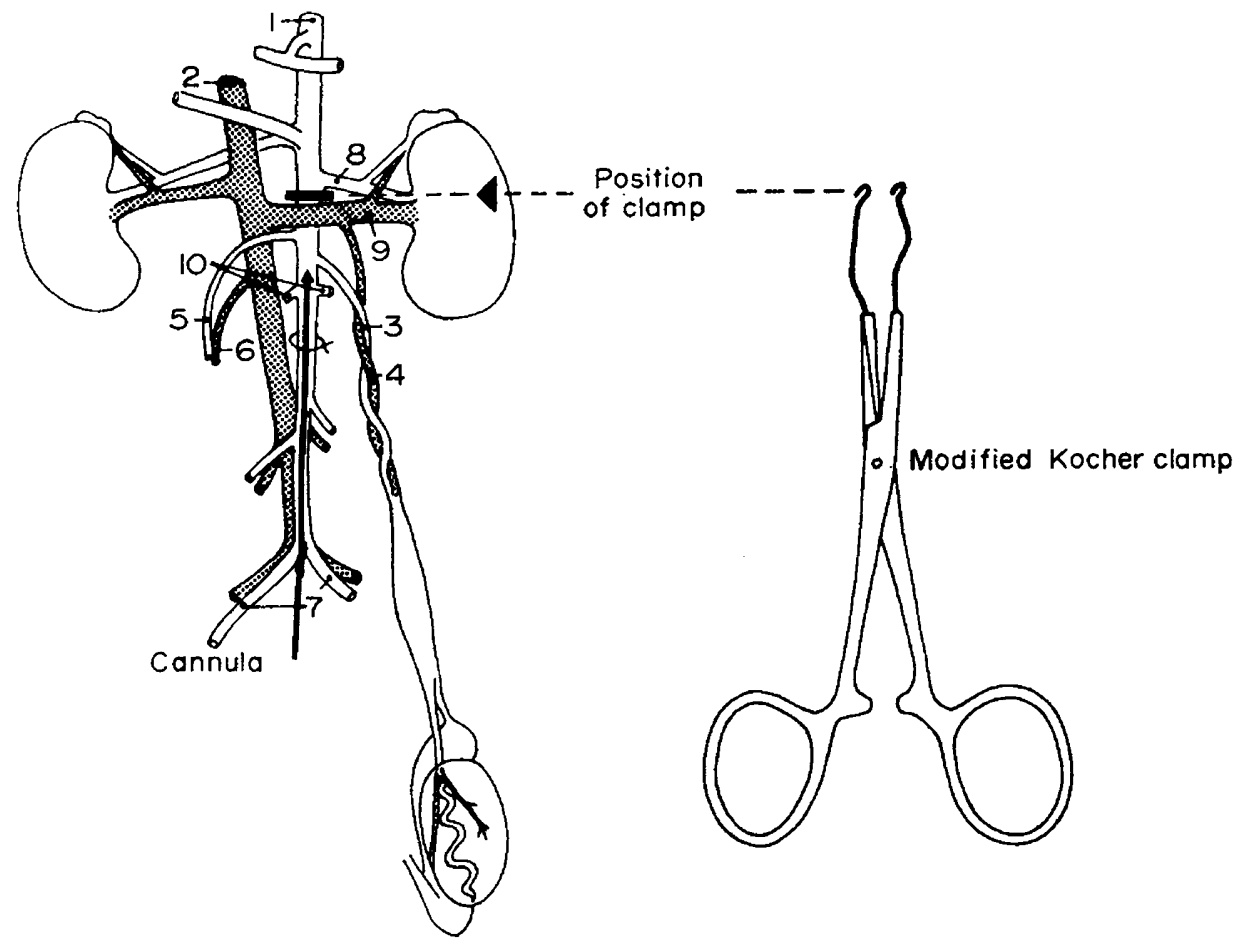

TEXT-FIG. 2. The blood vessels involved in the surgical procedure, showing (1) abdominal aorta, (2) vena cava, $(3,4)$ left internal spermatic artery and vein, $(5,6)$ right internal spermatic artery and vein, $(7)$ common iliac arteries, $(8,9)$ left renal artery and vein, 2nd (10) third pair of lumbar arteries. Part of the jaws were removed from the arterial clamp. On the remaining parts, two stainless steel wires $(0.8 \mathrm{~mm}$ o.d.) were attached with closely fitting semicircular blunt hooks.

internal spermatic artery which are difficult to clamp and which run to the epididymal fat and to the caput epididymidis. Anastomoses were also observed between the epididymal branch of the internal spermatic artery and the deferential artery which supplies the cauda epididymidis (Niemi \& Kormano, 1965).

Electron microscope pictures of testis were obtained after glutaraldehyde $(2.5 \%$, in sodium cacodylate buffer at $\mathrm{pH} 7.4)$ perfusion according to the method described, followed by post-fixation in $\mathrm{OsO}_{4}$ and routine dehydration, embedding and staining of thin sections. There was no ultrastructural evidence for hypoxia (Trump, Goldblatt \& Stowell, 1965) or for tubular damage due to 
the perfusion conditions (Linzell \& Setchell, 1969), since the tubular structure appeared normal and Leydig cell mitochondria had matrix granules.

Perfusion in situ has greatly contributed to the characterization of oestradiol$17 \beta$-binding in the testis, because the radioactive oestradiol infused through the internal spermatic arteries was readily taken up by the cytosol in the testicular

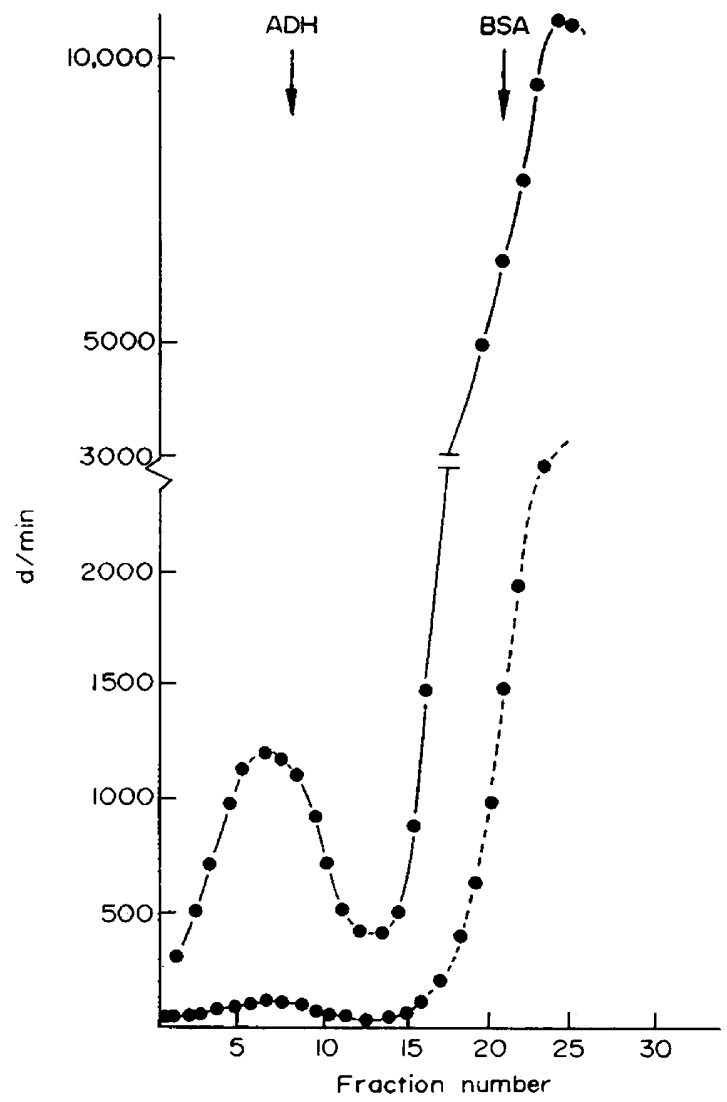

TExT-FIG. 3. Sucrose-gradient analysis of oestradiol-17 $\beta$-binding by cytosols of interstitial tissue $(-)$ and seminiferous tubules $(----)$. The amount of radioactive oestradiol (d/min) in each fraction is given as a function of the fraction number. Cytosol fractions ( $105,000-\mathrm{g}$ supernatant) were labelled by infusion with $10^{-10} \mathrm{~mol}(10 \mu \mathrm{Ci})$ of oestradiol$17 \beta$ into the testis and $200 \mu \mathrm{l}$ (about $3 \mathrm{mg}$ protein) of each fraction were layered over linear sucrose gradients $(5$ to $15 \% \mathrm{w} / \mathrm{v})$. The gradients were centrifuged for $18 \mathrm{hr}$ at $49,000 \mathrm{rev} / \mathrm{min}$ in a Beckman L-65 B ultracentrifuge equipped with an SW 65 rotor. After centrifugation, approximately thirty fractions were collected from each centrifuge tube. Radioactivity in the fractions was determined by liquid scintillation counting. Bovine serum albumin (BSA, $\mathrm{S}_{20, w}: 4 \cdot 6 \mathrm{~S}$ ) and yeast alcohol dehydrogenase (ADH, $\left.S_{20, w}: 7.4 S\right)$ were used as markers for calculation of the sedimentation value. The position of the markers is indicated by arrows. (From Brinkmann et al., 1972.)

interstitial tissue. Far less radioactivity was found in the cytosol of the seminiferous tubules (Text-fig. 3).

The sedimentation profile of the interstitial cell cytosol showed a sharp peak of radioactivity in the $8 \mathrm{~S}$ region. Only a small elevation in the corresponding region of the sedimentation profile was found for the tubular cytosol. The 
specificity and affinity of this binding principle have been discussed by Brinkmann, Mulder, Lamers-Stahlhofen, Mechielsen \& van der Molen (1972).

\section{REFERENCES}

Brinkmann, A. O., Mulder, E., Lamers-Stahlhofen, G. J. M., Mechielsen, M. J. \& van der Molen, H. J. (1972) An oestradiol receptor in rat testis interstitial tissue. FEBS Lett. 26, 301.

Christensen, A. K. \& Mason, N. R. (1965) Comparative ability of seminiferous tubules and interstitial tissue of rat testes to synthesize androgens from progesterone- $4-{ }^{14} \mathrm{C}$ in vitro. Endocrinology, 76,646 .

Cooke, B. A., De Jong, F. H., van der Molen, H. J. \& Rommerts, F. F. G. (1972) Endogenous testosterone concentrations in rat testis interstitial tissue and seminiferous tubules during in vitro incubation. Nature, Lond. New Biol. 237, 255.

EIK-NEs, K. B. \& HALl, P. F. (1965) Secretion of steroid hormones in vivo. Vitams Horm. 23, 153.

Greene, E. C. (1963) Anatomy of the rat, p. 199. Hafner Publishing Co., New York and London.

Linzele, J. L. \& Setcheld, B. P. (1969) Metabolism, sperm and fluid production of the isolated perfused testis of the sheep and goat. F. Physiol., Lond. 201, 129.

Niemi, M. \& Kormano, M. (1965) An angiographic study of cadmium-induced vascular lesions in the testis and epididymis of the rat. Acta path. microbiol. scand. 63, 513 .

Rommerts, F. F. G., van Doorn, L. G., GaljaArd, H., Cooke, B. A. \& van der Molen, H. J. (1973) The use of wet and dry dissection techniques in the investigation of seminiferous tubules and interstitial tissue from rat testis. $\mathcal{F}$. Histochem. Cytochem. 21, (in press).

Trump, B. F., Goldblatt, P. J. \& Stowell, R. E. (1965) Studies on necrosis of mouse liver in vitro. Lab. Invest. 14, 343.

VanDemark, N. L. \& Ewing, L. L. (1963) Factors affecting testicular metabolism and function. I. A simplified perfusion technique for short term maintenance of rabbit testis. F. Reprod. Fert. 6, 1. 